\title{
The Sustainability of Mediterranean Port Areas: Environmental Management for Local Regeneration in Valencia
}

\section{Filomena Borriello}

Department of Conservation of Architectural and Environmental Heritage, University of Naples Federico II, via Roma 402, Naples 80132, Italy; E-Mail: filomenaborriello@alice.it; Tel.: +39-0823-758-564

Received: 5 September 2013 / Accepted: 10 September 2013 / Published: 30 September 2013

\begin{abstract}
Urban renovation projects, which have led to the conversion of port areas through a new vision of waterfronts as elements of the potential development of the urban system in its entirety, have spread since the early 1950s and now some port cities are able to trigger some mechanisms which, even if they are the result of some processes that have been activated for decades and which are still evolving, are able to amplify and to extend over time their generated positive impacts. These impacts also produce a system of relations in the context of the hinterland, attracted also by policies of economic, social, and cultural development. In the case of the city of Valencia, we have seen, in the last 50 years, a progressive spread of the urbanized area to the coasts, simultaneously with a process of renovation of the port area, which has been populated by important architectures, and which has been equipped by efficient infrastructures and subjected to numerous recovery and restoration operations of its historic buildings. However, the environmental conditions near the port area are not well suited to a good quality of life because ports are pollution producers, sites of urban decay, and of social degradation. A good plan can include some instruments to decrease those negative factors, leading to a close merging between the port area and the city hinterland, and generating new economies. The proposal of this research consists in a method of integrating the port planning with an environmental accounting system.
\end{abstract}

Keywords: port city; emissions impact; strategic projects

\section{Introduction}

In recent decades, the role of ports in the Mediterranean Sea has been marginal, when you consider the strategic importance of the Northern Range ports (including the ports of Rotterdam, Le Havre, and Hamburg) located on the Atlantic routes; but recently, geo-economic and technological world 
changes have "hijacked" the traffic (especially the commercial traffic) on other routes, strengthening the Pacific-Mediterranean-USA axis and the potential increase in traffic between Europe and Asia, leading the Mediterranean Sea to have a crucial role due to its privileged position. To these factors we should add government and financial measures such as: legislation in favor of the establishment of offshore activities in Malta, public investments in port infrastructures in Spain, the establishment of the Port Authority, and the liberalization of port operations at the docks in Italy.

Comparing the movements in the last four years between the container terminal ports of the northern European coast of the continental European Union (France, Belgium, Holland, Germany, Poland), those of the Western Mediterranean Sea, and those of the Adriatic Sea (Spain, France, Italy, Slovenia, Croatia, Greece), the Mediterranean terminals contributed 55\% of the increase in the total number of movements, having brought their share of participation to $43 \%$ of the total [1].

Currently, the port of Valencia (Figure 1) located on the western coast of the Mediterranean Sea and including the ports of Sagunto and Gandia, is the leading Spanish port for commercial traffic and it is the first and last port of the main interoceanic maritime line of the Western Mediterranean. The regenerative process of the port has been implemented into a more general strategy, therefore this experience can be considered as a good exercise in terms of efficiency and effectiveness and could be offered to other port cities, assessing and adapting it to different contexts as suggested by point " $\mathrm{f}$ " of the Habitat Agenda.

Figure 1. The port of Valencia.

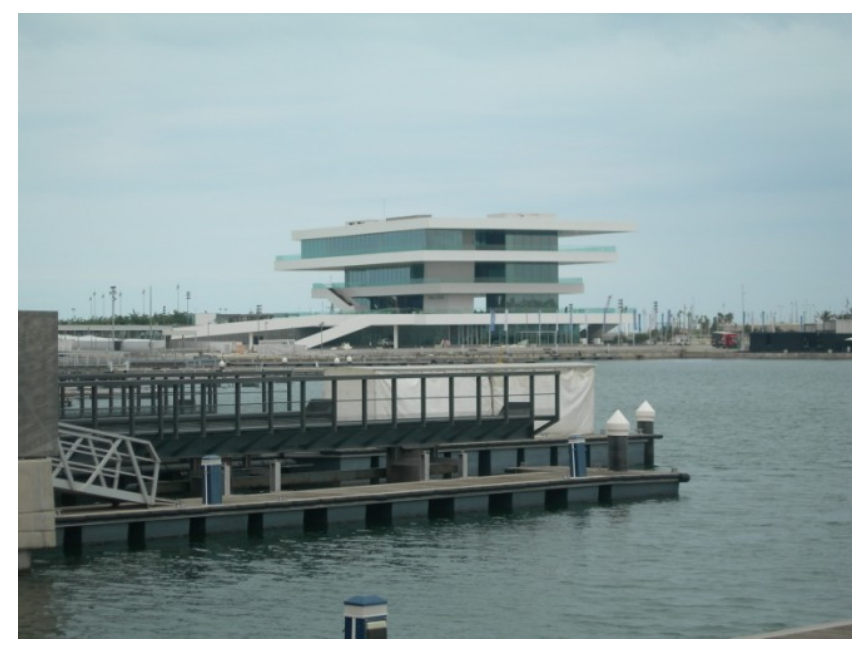

(a)

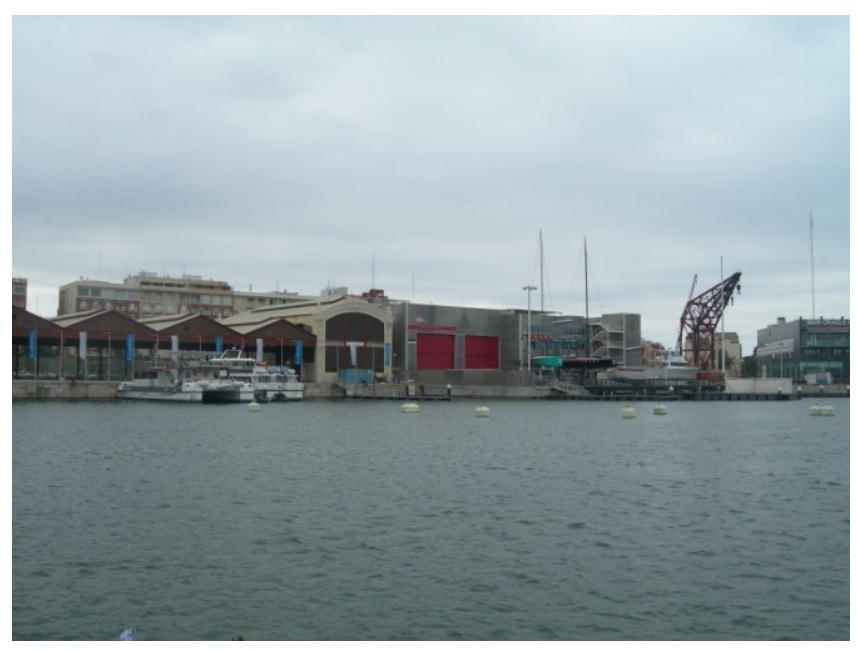

(b)

The experience leads to the following benefits:

$\checkmark$ The commercial port that is the closest to the Suez-Gibraltar axis, the main route of the interoceanic lines;

$\checkmark$ Easy for traffic concentration and distribution in the Western Mediterranean Sea.

Moreover, the enviable position of the Iberian Peninsula makes this port the natural harbor for interoceanic freight traffic by providing:

$\checkmark$ Short times for land transport;

$\checkmark$ Ample opportunity for redistribution of goods both to and from the Peninsula. [2]. 
The regenerative process of the city of Valencia is mainly supported by the Valenciaport strategic plan (2002-2015), which attends to port logistical equipment and develops many strategic lines with the aim of reinforcing the competitiveness of the port. This strategic plan has characteristics of flexibility and adaptability, and is constantly updated; through review processes, it relates to the changes of the boundary conditions: its tendency to be adaptable to new economic and environmental scenes makes it innovative in itself. Valenciaport is implemented through 25 priority strategic projects and is articulated through the following seven lines of actions:

(1) Redevelopment of the port access and infrastructures;

(2) Integration of the port and city;

(3) Constant innovation of port services;

(4) Expansion of areas of influence;

(5) Increase in transoceanic connections;

(6) Implementation of logistics development;

(7) Development of intermodal services [3].

The plan in brief:

- To consolidate the port of Valencia as the main gateway of Spain;

- To make the port of Valencia the most important for regional distribution and to make it the main logistics platform of the Mediterranean area;

- To make the port of Valencia capable of managing (in 2015) traffic of about 68 million tons of TEU.

Strategic urban planning has been able to generate a form of attraction towards the hinterland of the urbanized area, triggering a process of rapprochement that has reinstated it with its waterfront: the relationship of the city with the sea is the driving force for local development and the waterfront is a portrait of the competitiveness and attractiveness of the city in the international scene. Valencia has been able to recover its "maritime identity" [4], it has lived through the growth of the positive impacts of its revitalization, and potentially it can still expect growth with economic, social and cultural development through the integrated strategies adopted by long-term prospects.

The most important socio-economic growth of ports' activities produces big benefits on a local scale. The urban hinterland of many Mediterranean port cities expanded its territory towards the coastal area and especially towards its port area, searching for new impulses for the economic growth of the city; but for many reasons, ports still remain only a workstation or a transportation platform and the hinterland continues to be the best place to live a healthy life. One of the reasons for this marked distinction is the environmental degradation of port areas that worsens considerably the quality of life of the local inhabitants. The ships at berth consume fuel and produce noise and vibrations generating different types of pollution to all the natural coastal elements: the water, the air, and the seabed.

There is a type of approach motivated by a possible change in the improvement of the quality of life by monitoring environmental quality (air quality, acoustic quality, water quality, etc.) and by establishing methodologies that will encourage companies to remain committed to environmentally respectful activities: Environmental Management Systems [5]. 
This paper aims to extract, from this good practice, a lesson that can support a model for environmental governance in other port cities and port areas, a model that can be repeatable, in particular, in the southern ports of the Mediterranean area.

Thus, the paper is structured in the following way: (1). Introduction, for the presentation of the research project; (2). The key problem to solve, i.e., the conflict between the pollution of ports and urban quality of life; (3). The presentation of Valencia as good practice with the description of its port area, its area of interface of its environmental situation and of the project adopted with the aim of the improvement of the environmental quality; (4). Lessons learnt; (5). The research proposals for an Environmental Accounting System in port areas; and (6). This contains some critical conclusions about the research.

\section{A Key Problem: The Conflict between the Pollution of Ports and Urban Quality of Life}

Speaking about global maritime transportation, international fleet statistics [6] say that over 100,000 ships put into 45,000 ports across the world, generating 900 million tons of $\mathrm{CO}_{2}$, equal to annual emissions into the air of about 220 coal-burning power plants, about $7 \%$ of the total $\mathrm{CO}_{2}$ emissions, but also emit $\mathrm{SO}_{\mathrm{x}}, \mathrm{NO}_{\mathrm{x}}$, and particle discharge into the atmosphere, which are very toxic for health and dangerous for the environment. Ships are one of the main pollution producers because of the sulfur content in fuel, and to reduce emissions we cannot ignore ships or replace them with other forms of transport: for example, maritime traffic, in the last 20 years, has produced double the greenhouse gas emissions of those produced by aircraft. However, maritime traffic potentially ensures a larger quantity of transported freight than aircraft.

In November 2007, the ANSA (Agenzia Nazionale Stampa Associata) disclosed a study of "Environmental Science and Technology", according to which air pollution originating from ships is responsible for the death of 6000 people every year, as well as causing environmental damage (which is sometimes fatal), and also being the cause of damaging cultural heritage because it accelerates acidification processes [7]. Despite several regulations by IMO/MARPOL (Organizzazione Marittima Internazionale/Marine Pollution) and the EU, ships continue to cause environmental damage, but there are some hypothetical solutions to be adopted which can lead to a decrease in the emission of pollutants into the atmosphere, from the use of the finest fuel for ships (containing less sulfur), proceeding with the suspension of ships' engines in the port areas (avoiding burning fuel during stops), to measures to reduce car traffic near the port area and limitation of cargo road operations throughout the terminals.

The pollution of port water and the coastal seabed is caused by detritus and oleiferous mud (metals, hydrocarbons, nutrients, bacteria, chemical substances, etc.) produced by docking ships, by equipment structures, and shipbuilding activities, susceptible to storage for living organisms. The sea has defended itself against these pollutants with more or less efficient natural actions such as photodegradation and dilution; in some cases, these mechanisms fail to trigger effectively: the case of the Mediterranean Sea is, in fact, emblematic of an enclosed sea that presents little transparency and is rich in inorganic substances.

One of the central aspects of the pollution of marine ecosystems is the accumulation of harmful substances in food chains because it has serious consequences for bioaccumulation and persistence of 
these substances, as well as for their pathogenicity, which can affect, in practice, each organ and system. This aspect also highlights the potential spread of toxic substances, which is completely unpredictable and confinable only to areas adjacent to the polluted water.

So chemical analysis of water, detritus, and the seabed should first identify harmful substances; the dredging and the cleaning of the seabed and the installation of scrubbers would make water healthier, near and beyond the port areas.

In regard to vibration and noise associated with port operations, such as ships' engines on board, shipyards' activities, handling and maneuvering of loads, among other things, they create an environment that is less hospitable for workers, and is also unpleasant for nearby residents. That can make it difficult for ports to expand their operations. The high noise level in the proximity of port areas is also influenced by road traffic: often ports are separated from the hinterland by large roads contributing to creating two different entities: the port and the city.

So the presence of negative elements such as pollution, and the high energy expenditure (of conventional sources), generates a low quality of life, especially in regard to the housing needs of healthy sites producing a separation that makes a strong sign of demarcation of the areas (port and hinterland): they cannot communicate with each other in any way.

\section{Valencia as Good Practice}

\subsection{The Integration of a City with Its Port}

The port cities have a deep relationship with the sea that very often, as in the case of Valencia, is identified as a driver for the development of the first urban settlement of the historic city. The port area and the coast are hinge elements joining the sea and the hinterland; the fracture, which can occur between city and port, can be triggered by several factors:

- Physical: the two areas of the town centre are separated by built elements, which delineate the boundaries.

- Administrative: the two entities are managed by different bodies (the Port Authority and the Municipal Administration) and the tools of planning and management procedures are different in the two areas.

- Social and cultural: the quality of life is at the lowest level in the port and in the immediately adjacent area for reasons such as the lack of services, the factors of environmental pollution, and the urban and social decay that characterizes these places.

Recovering the relationship with the sea and reconnecting the city with its port means recapturing "the identity of the sea city" [8], which means recovering its genius loci, the culture and collective maritime memory, through spaces, forms, and functions.

The city of Valencia, in recent decades, has managed to become a magnet for a high media profile, projecting itself on the international scene as a leading port city in Europe. Along with its strategic location in the Mediterranean basin, its importance as the leading Spanish port, its urban image and its scenic waterfront, and its capacity to attract major sporting events, are certainly the result of overall strategic planning. Its waterfront has become a major urban laboratory [9] that has been able to enhance the attractiveness of the city, creating added value: by increasing the perception and the visual 
quality, it has been able to centralize the location of new economic activities generating an image of an entrepreneurial port city [10].

The history confirms its importance as a port city: in 1500 it hosted the taula de canvin de la ciutat de Valencia, a municipal bank operating, at that time, to finance merchant activities and to promote the exchange rate [11]; the port, together with the navigable River Turia, constituted an efficient integrated system for transportation which played, for Valencia, an important role in the 15th and 16th centuries, during which it became one of the main commercial centers of Europe and lived its "Siglo D'oro" [12]. The years following the discovery of America involved a slow regression of commercial business, entering the 18th century with a completely disused port. Then, for a long time, the city was closed to the sea, and as a result of the population growth, Valencia expanded beyond the old demolished walls, towards the hinterland. Since the early 1960s there has been a gradual development of the port and the coastal area through the implementation of a series of interventions: following the deviation of the Turia began the achievements of the Jardin designed by Ricardo Bofill (Figure 2), following the flooding of 1957, with the Plan Especial De Ordinación de Cauce Turia, and the redevelopment of the waterfront.

Figure 2. The Jardín del Turia, R. Bofill.

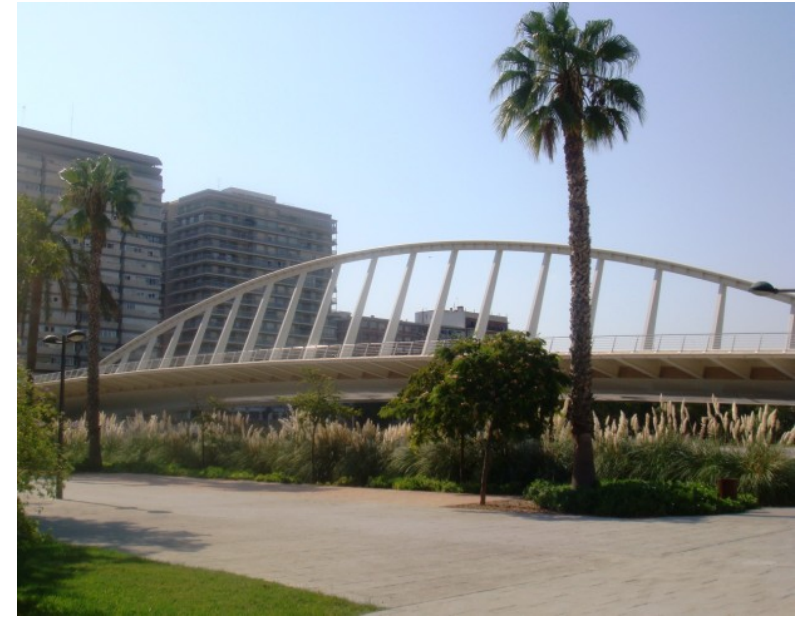

(a)

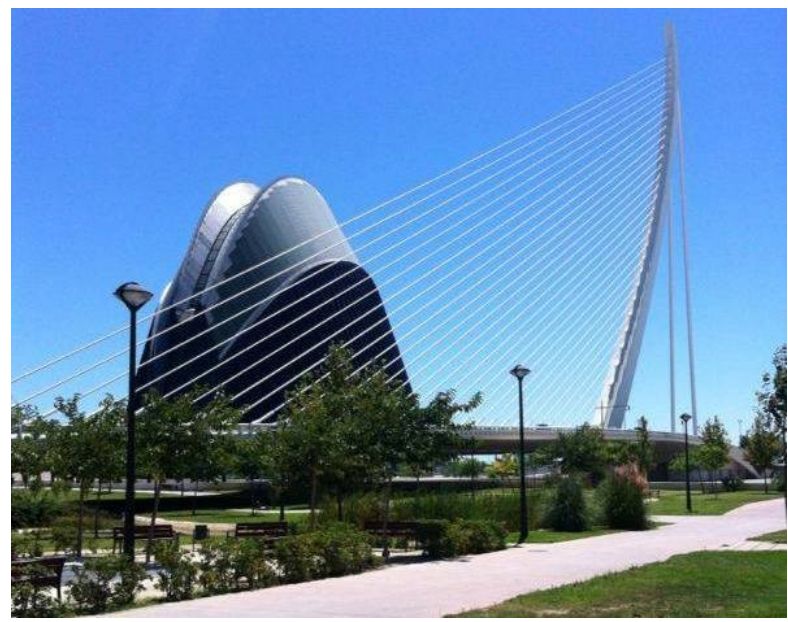

(b)

In addition to Bofill, various internationally renowned architects have contributed to the metamorphosis of Valencia (Figure 3): Jose Maria Barcia De Paredes with the Palau de la Musica, Santiago Calatrava with La Ciudad de las Artes y las Ciencias, Norman Foster with the Palau de Congresos, the architect Jose Maria Tomas Llavador with the Balcón al Mar by D. Chipperfield Architects, and b720 Arquitectos of Barcelona with Veles y Vents. The implementation of major infrastructures has supported these famous architectures such as: the port, the airport, the underground, the exhibition center, and accompanied by development projects of the beaches (El Saler, Pinedo, Malvarrosa) and of the Albufera Park.

These large urban projects have contributed to a transformation of the city that has seen the breakdown of the limits and the distance between the hinterland and the coast, creating a rapprochement of the two entities driven by the attraction of the economic, cultural, and material potential that the coast has been able to exert. 
Figure 3. (a) The Palau de la Musica; J. M. Barcia de Paredes; (b) Veles Y Vents, D. Chipperfield Architects and B720 Arquitectos of Barcelona; (c, d) La Ciudad de las Artes y las Ciencias, S. Calatrava.

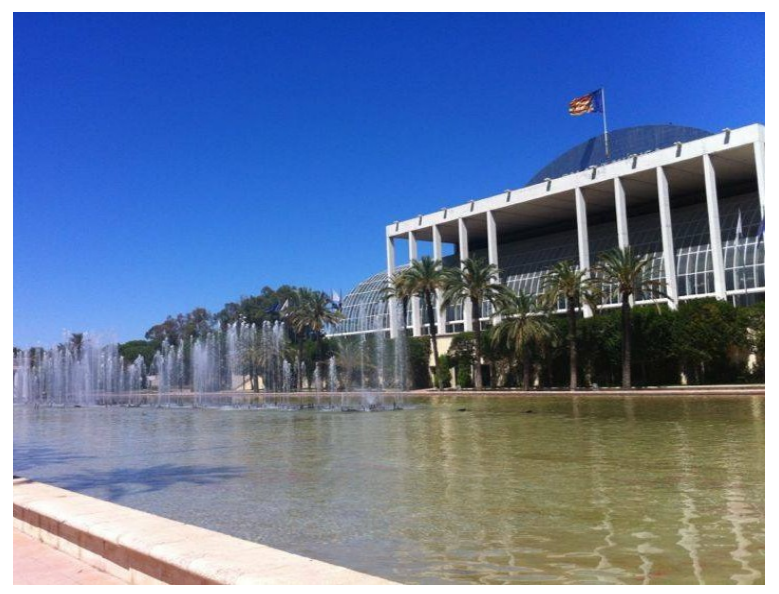

(a)

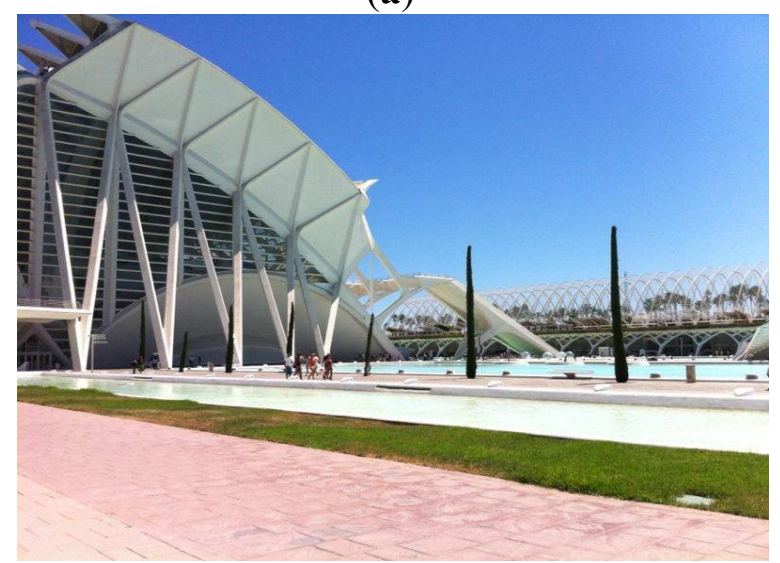

(c)

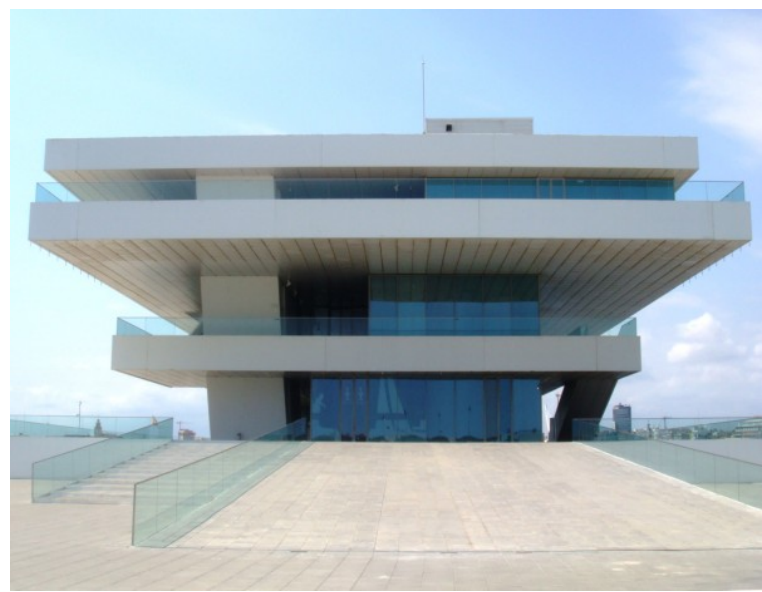

(b)

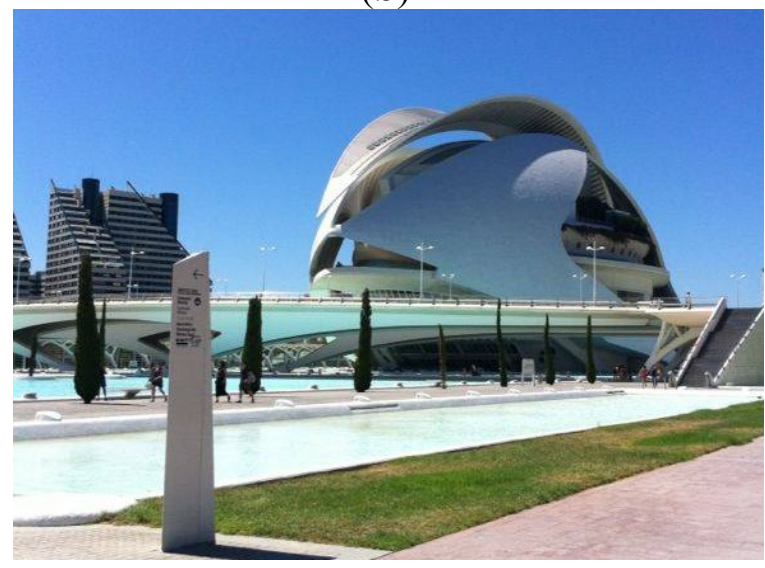

(d)

The renewal process of Valencia also included attracting people towards media events of great international impact: the America's Cup, and, since 2003, large-scale interventions have been planned for the waterfront: the dock (in a state of major degradation) has been reclassified as the base for teams participating in the competition, a new channel has been created to reconnect the same dock with the sea, new buildings, new public spaces, and new infrastructures have been realized, together with the recovery of the ancient port. In 2006, it was recognized by the World Tourism Organization as the first European destination to receive credit for the implementation of best practices in managing and promoting tourism, and in 2008 received the "Ulysses" for the same achievements. It has hosted international sporting events such as Formula 1, the Volvo Ocean Race, the Open 500, the World Indoor Athletics Championship, and of course the America's Cup, and for this reason it has been selected as a case study by the Center for Sport Business Management in the forum "Major Sports Events as Opportunities for Development: the International Promotion of the City" held in Valencia itself [13].

All of these events are accompanied by the integrated planning of Valenciaport and, on the issue of "sustainability", we still find Valencia, and its port, at the forefront of measures to reduce harmful emissions into the air and water (mainly) in the form of international membership plans with these purposes. These operations to mitigate the impacts contribute to the rapprochement of the city with the 
port area: improving environmental conditions at the boundary improves quality of life and eco-systemic conditions. Thus, people re-establish their relationship with the port, with its activities and with the sea. The area of the "port city" interface can become more livable, more usable, more habitable, free from demarcations, and part of the waterfront.

\subsection{Adherence to Projects for the Improvement of Environmental Quality}

The membership of projects initiated by international impact institutions to an environmental policy, for the promotion of plans for the protection of natural resources, is a strategy adopted by many European cities and not intended to be screened on the international scene. The effects of a policy of participation in European and international projects can be of different types and of different impacts:

- Financial return;

- Direct growth of employment and company establishment;

- International cooperations;

- Public-private cooperation and knowledge transfer;

- Creation and consolidation of networks;

- Access to other financing programs;

- Knowledge production and dissemination of results;

- Impact on policy research in the participating institutions.

The Port Authority of Valencia, as a manager of major Mediterranean port authorities, takes as a priority, in its business strategy, the adoption of an environmental policy consistent with the port activities in its area of competence. The city of Valencia and the port authority have joined different projects and plans including some international plans that can be considered very important from the point of view of environmental sustainability, in particular with the aim of controlling and monitoring the environmental situation in the ports.

Valenciaport has been chosen as one of the EMAS (Eco-Management and Audit Scheme) case studies, specifically for "Commitment in the protection of the Mediterranean" [14], with the aim of adapting the EMAS certification to the port areas; demonstrating its commitment, it has developed some strategic programs and some important projects addressing environmental sustainability [15,16]. Among these projects, we list below some of them that constitute many important forms of activation.

\subsubsection{Completed Projects}

\section{EcoPort}

\section{Towards an Eco-friendly Port Community}

- Financing: European community within the LIFE (Financial Instrument for Environment) Program;

- Duration: 1998-2001;

- Total budget: 839,080.60€;

- EU contribution: 419,540.30€;

- Aim of the project: To develop an Environmental Management and Audit System for port areas, developing the EMAS validation for port contexts. 


\section{INDAPORT}

System of Environmental Indicators for Ports

- Financing: the Program for the Promotion of Technological Research (PROFIT) of the Ministry of Science and Technology;

- Duration: 2000-2003;

- Aim of the project: to elaborate environmental indicators which could be reproduced in other port environments.

\section{HADA}

An automatic tool for environmental diagnosis

- Financing: EU via the LIFE Program;

- Duration: 2005;

- Aim of the project: to project a system of air and noise pollution reduction in port areas linked to a decision-making process.

\section{EcoPorts}

- Financing: V framework program of the European Commission

- Duration: 2002-2005

- Aim of the project: TO develop a series of tools for the EMIS (Environmental Management and Information System)

\section{SECURMED}

An Interregional and Transnational View of Maritime Security and Environmental Protection in the Western Mediterranean

- Financing: Interreg IIIB Project of the European Commission;

- Duration: 2004-2007;

- Total budget: $1,404,800 €$;

- Aim of the project: to elaborate a security system for monitoring the environmental management of port environments.

Elefsina Bay 2020

- Financing: LIFE Program of the European Commission under the reference Life 05 ENV/GR/000242;

- Duration: 2007-2008;

- Aim of the project: to reduce pollution and maritime accident risk involving dangerous goods in Elefsina Bay (Greece).

\section{MADAMA}

- Financing: European Commission as part of the Interreg IIIB Medocc Program;

- Duration: 2005-2008;

- Aim of the project: TO understand, define and harmonize all actions in relation to monitoring and protecting the hazardous goods chain in the Mediterranean. 
Improvement in the environmental management of ports in the Gulf of Honduras

- Financing: Banco Interamericano de Desarrollo' and with Spanish Cooperation Funds;

- Duration: 2008;

- Aim of the project: to mitigate environmental impact and to protect the Mesoamerican Barrier Reef System.

MADAMA

- Financing: European Commission as part of the Interreg IIIB Medocc Program

- Duration: 2005-2008

- Total budget: $500,000 €$

- Aim of the project: TO understand, define and harmonize all actions in relation to monitoring and protecting the hazardous goods chain in the Mediterranean

Eco-logistyport

Environmental training in small and medium-sized companies in the port logistics sector in the $V$. $C$.

- Financing: European Social Fund, the Biodiversity Foundation and the Polytechnic University of Valencia, in conjunction with the Valencia Port Authority and ITENE (Instituto Tecnòlogico del Embalaje , Transporte y Logìstica)

- Duration: 2008-2010;

- Aim of the project: to implement environmental management systems and energy-efficient systems.

\subsubsection{Main Projects}

NoMEPorts (Noise Management in European Ports)

- Financing: LIFE Program of the European Commission;

- Duration: 2005-2008;

- Aim of the project: "The EU Directive 2002/49/EC establishes that the administration should evaluate (through specific programs) the noise in the port and industrial areas close to large urban areas; but the Directive does not specify how to define these programs' noise assessment. The initiative taken by the European ports that have joined the NoMePorts project (Administration of Noise in Ports) is to develop good practice guidelines on how to identify those areas in which an industrial port and the specific combination of traffic and activity affect the levels of noise" [17] using new methods of calculation of noise that have already been developed in a previous community project called HARMONOISE. For this project the Port Authority of Amsterdam is the leader, while the Port Authorities of Livorno, Hamburg, Copenhagen/Malmoe, Civitavecchia and Valencia are the partners of the project. A noise policy can contribute to reducing the health risks for humans and also the dangers for the environment.

SIMPYC (Environmental Integration for Port and Cities)

A system for port-city environmental integration

- Financing: LIFE Program of the European Commission;

- Duration: 2005-2008; 
- Aim of the project: the aim of this project consists in establishing "good relations in areas of port-city interaction thereby contributing to a more harmonious coexistence in socio-environmental terms" [18]. In particular, according to the aim of this research paper, it has the purpose of developing a relationship between the port area and the city hinterland, monitoring the environmental healthiness through the condition of natural elements like water, air and soil. This specific objective has to be implemented by developing an EMS strategy aiming to establish the relationship between socio-economic aspects and environmental conservation, to coordinate port and city governments, to control noise and air pollution, and to diffuse information about environmental sustainability.

\section{CLIMEPORT}

Contribution of Mediterranean ports to mitigating the effects of climate change

- Financing: European Union via the MED program;

- Duration: 2009-2012;

- Total budget: $1,610,454.00 €$;

- ERDF (European Regional Development Fund) contribution: 1,239,221.00€;

- Aim of the project: to reduce greenhouse gas pollution (GHG) by evaluating' the impact and the influence of port area activities on climate change to increase the quality of life in cities adjacent to ports: "ports, with the collaboration of all parties in the logistic chain, must reduce greenhouse gas emissions, focusing on: reducing vessel emissions, reducing emissions from terminal operations, innovative transport, energy efficiency and air quality". The project has developed a benchmarking process to verify the use of "best practices" that reduce the environmental impact and the use of renewable energy in ports and it aims to develop solutions in order to improve the climate conditions by means of actions in maritime and inland transport, by energy saving and efficiency and by implementing the world port climate declarations. For these reasons, CLIMEPORT sets several actions and initiatives to develop a diagnosis of the influence of ports on climate change and action plans for reducing the port activities' impact on the environment. In particular, the main objective of the plans is "to evaluate the contribution of the Mediterranean ports to the different environmental aspects which are involved in climate change and thus develop tools and best practices that can be widely used to mitigate the contribution of Mediterranean ports to climate change, including environmental risks" [19].

EFICONT (Energy Efficiency in Container Port Terminals)

- Financing: Ministry of Public Works;

- Duration: 2009-2010;

- Aim of the project: the aim of this project is to improve the energy efficiency of port areas, especially in container port terminals. It promotes sustainable mobility through the modernization and improvement of ancient equipment but also through new technologies in new equipment. Energy efficiency applied to container terminals conduces to the improvement of port productivity and simultaneously of machinery efficiency, reducing energy consumption and operational costs and increasing port competitiveness. 


\subsubsection{Some Critical Considerations}

The environmental policy adopted by Valenciaport was approved on 12 April, 2000. Since this date we have seen progressive adherence to the previous projects considered as good experiences for the sustainable development of the city. The biennium 2007-2008 was the most profitable period (Figure 4).

Figure 4. Temporal comparison graph.

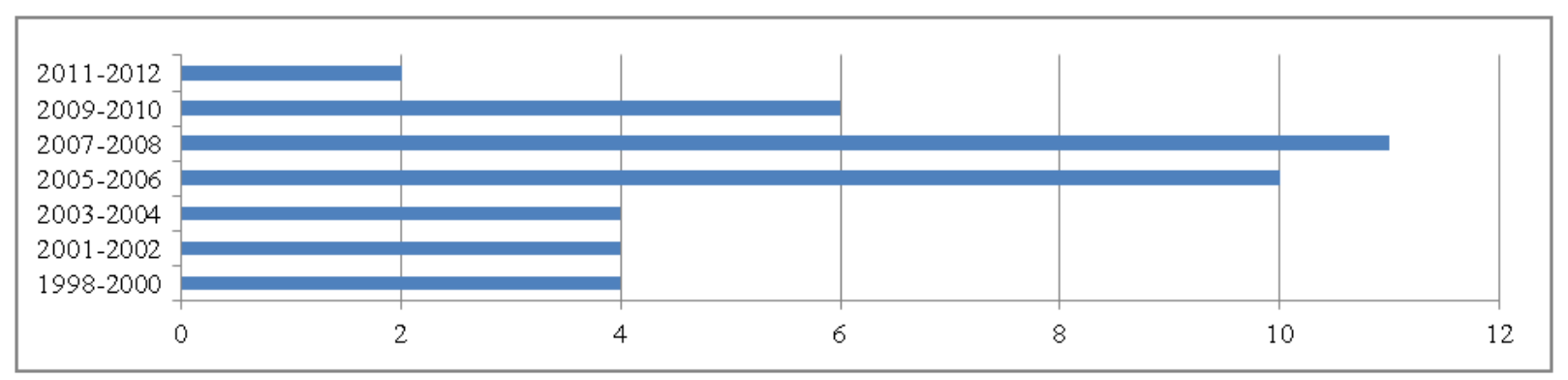

The common aim of all the previous projects is the elaboration of an Environmental Management System for port areas, shared by the other Mediterranean ports. The following table takes into account the objectives specified for each program; this type of analysis highlights the most quoted areas of expertise for the Valencia environmental policy.

\subsubsection{Some Concrete Actions of Valenciaport}

The port of Valencia, as well as having joined actively in these and other projects (see Table 1) aimed at environmental sustainability, has also supported measures of sediment management and dredging: it was realized a new harbor square, with an area of 50,000 $\mathrm{m}^{2}$, starting from the mass stabilization of dredged marine sediments in marine-coastal front of the port and then moved inside the filled tank. The new port area has been used as a dock for containers. The Port Authority of Valencia, in collaboration with the Polytechnic of Valencia, has also developed and implemented a project for the installation of equipment for the production of electricity from wind power, taking advantage of the currents with low visual impact; they also used photovoltaic technology, installing $300 \mathrm{kw}$ in the Valencia Port Authority car parking. Finally, using cold ironing they applied a land-based power supply to ships project Alternative Maritime Power (AMP), through which ships can use the required power while docking without operating their own generator but using power produced by the port [20]. The energy efficiency diagnosis on public lighting is another tool for fighting against climate change: the APV adopted a lighting plan to reduce $\mathrm{CO}_{2}, \mathrm{SO}_{2}$, and $\mathrm{NO}_{\mathrm{x}}$ emissions and to control the network dispersions. At the same time, Valencia has developed an environmental network monitoring through three principal key elements: "Air quality, Water quality, Noise Quality" [21].

So through a Meteorological Instrumentation Plan (a system of meteorological stations), they can control the air quality in real time, monitoring the important environmental parameters $\left(\mathrm{NO}, \mathrm{SO}_{2}, \mathrm{CO}_{2}\right.$, and PM10 levels). There is also a noise control network through the CITRIX server and a water quality control, which takes place through monitoring "hydrology, microbiology, plankton, and benthic communities inside the port area over a yearly cycle; a network of sensors, evaluate the conditions 
of: water temperature, chlorophyll, O2, hydrocarbons, turbidity, salinity, direction, and wave intensity" [22].

Table 1. Project objectives.

\begin{tabular}{|c|c|c|c|c|c|c|c|}
\hline $\begin{array}{l}\text { Areas of } \\
\text { expertise* }\end{array}$ & \multicolumn{7}{|l|}{ Projects } \\
\hline \multicolumn{8}{|l|}{$\begin{array}{l}\text { I.Environmental } \\
\text { management }\end{array}$} \\
\hline \multicolumn{8}{|l|}{$\begin{array}{l}\text { II.Natural } \\
\text { environment and } \\
\text { sea resources } \\
\text { protection }\end{array}$} \\
\hline \multicolumn{8}{|l|}{$\begin{array}{l}\text { IIIIEmissions and } \\
\text { Waste }\end{array}$} \\
\hline \multicolumn{8}{|l|}{$\begin{array}{l}\text { IV.Energy } \\
\text { resources }\end{array}$} \\
\hline \multicolumn{8}{|l|}{ V. Land use } \\
\hline \multicolumn{8}{|l|}{$\begin{array}{l}\text { VI. Sustainable } \\
\text { mobility }\end{array}$} \\
\hline \multicolumn{8}{|l|}{$\begin{array}{l}\text { VIIIProductive } \\
\text { activities }\end{array}$} \\
\hline \multicolumn{8}{|l|}{$\begin{array}{l}\text { VIIIITraining, } \\
\text { information and } \\
\text { participation }\end{array}$} \\
\hline \multicolumn{8}{|l|}{$\begin{array}{l}\text { IX.Port-city } \\
\text { integration }\end{array}$} \\
\hline \multicolumn{8}{|c|}{$*$ This table is elaborated in relation to Table 2.} \\
\hline \multirow{2}{*}{$\begin{array}{l}\text { Areas of } \\
\text { expertise* }\end{array}$} & \multicolumn{7}{|l|}{\begin{tabular}{|l|} 
Projects \\
\end{tabular}} \\
\hline & $\begin{array}{l}\text { Honduras } \\
\text { project }\end{array}$ & MADAMA & $\begin{array}{l}\text { Ecologisty } \\
\text { port }\end{array}$ & $\begin{array}{l}\text { NoME } \\
\text { PORTS }\end{array}$ & & & Eficont \\
\hline \multicolumn{8}{|c|}{\begin{tabular}{l|c}
$\begin{array}{l}\text { I.Environmental } \\
\text { management }\end{array}$ & $\mathbf{O}$ \\
\end{tabular}} \\
\hline \multicolumn{8}{|l|}{$\begin{array}{l}\text { II.Natural } \\
\text { environment and } \\
\text { sea resources } \\
\text { protection }\end{array}$} \\
\hline \multicolumn{8}{|l|}{$\begin{array}{l}\text { III.Emissions } \\
\text { and Waste }\end{array}$} \\
\hline $\begin{array}{l}\text { IV.Energy } \\
\text { resources }\end{array}$ & & & $\because$ & & & & \\
\hline \multicolumn{8}{|l|}{ V. Land use } \\
\hline $\begin{array}{l}\text { VI. Sustainable } \\
\text { mobility }\end{array}$ & & & & & & & 5 \\
\hline $\begin{array}{l}\text { VII.Productive } \\
\text { activities }\end{array}$ & & 今- & $\because$ & & & & \\
\hline $\begin{array}{l}\text { VIII.Training, } \\
\text { information and } \\
\text { participation }\end{array}$ & & & & & & i- & \\
\hline $\begin{array}{l}\text { IX.Port-city } \\
\text { integration }\end{array}$ & & & & & & & \\
\hline
\end{tabular}

\section{Lessons Learnt}

The strategy adopted by Valencia port was supported by a specific self-regulation, which had as its basis the following: the ESPO guidelines, the C40 World Ports Climate Declaration, the AIVP-IACP-Sydney Declaration. This environmental policy has allowed Valencia to obtain various certifications, including:

(1) In 2003 it obtained a certificate in the Port Environmental Review System (PERS).

(2) In 2006 it achieved certification for the EN ISO 14001-2004 Standard on Eco-management.

(3) In 2007 it received EMAS II Validation and Verification.

(4) In 2008 Valenciaport received the Eco-Excellence Award. 
VPA environmental policy is also involved in many cooperation projects for the improvement of environmental management through knowledge transfer. It has taken part in the European Economic Interest Group EUROPHAR since 2007 submitting different projects such as: AQUAPORT (New Approach on Water Quality Control and Monitoring in Port Areas), PASCAL (Early Detection of Biological Agents through Sensor Network and Sensor Fusion), and SUPPORT (Security Upgrade for Ports).

Confirming its commitment to environmental sustainability, in 2011 the Port Authority, with the reform introduced by law 48/2003 of November 26 named Régimen económico y de prestación de servicios de los puertos de interés general, processed the Convenio en Materias de Buenas Prácticas Ambientales, a document containing some important innovative measures to mitigate the impact of port pollution: in particular it proposed the emissions inventory for noise, air, water, and soil pollution, the detection of the annual consumption of energy and the installations' maintenance monitoring (to reduce any environmental risks).

Valencia, over the years, has thus proved to be good practice for the advanced strategic environmental planning adopted and coordinated by Valenciaport. The centralization of the governance has been one of the strengths for achieving the objectives of sector plans, ensuring a long-range vision and connecting the complexity of the systems in the port area.

Environmental policy, translated into concrete action, gives valiant merits to a port authority that used a lot of resources (of various kinds) in the fight against climate change, in the reduction of harmful emissions, and improving the quality of life of people who live along the port areas.

So the merging of a city with its waterfront is a transformation that involves both the waterfront and the inland urban core, activating processes based on urban regeneration and, at the same time, on the enhancement of the coastal area with great attention to environmental protection for human health.

In Italy, many strategic plans for port areas have the Energy Balance and at the same time the VAS (Valutazione Ambientale Strategica) for environmental impact assessment [23] and there is also the participatory component which acts as a strategy to generate consensus and as a table for discussion on the intervention policy (participatory balance). What is missing is the tool oh synthesis of the above mentioned that takes the form of Integrated Environmental Accounting. Only with this tool is it possible to implement the objectives of an integrated governance that will coordinate the energy policy, and environmental and social issues that, in relation to economic and financial factors, can support more informed choices consistently pursued by each of the sustainability aspects in the game.

The Environmental Accounting is just a tool for managing the impacts on the environment. Used, at first, by industry, it was an information document, which illustrated the relationship between industry and the environment, a communication tool able to provide transparent framework information on environmental policies pursued and prosecuted in the various branches of production [24].

The adoption of this Environmental Accounting System was then activated for more complex systems such as cities through which the directors, alongside the environmental balance in the economic-financial one, triggering processes of sustainable development, supported by the participatory factor of citizens, led to informed choices of future intervention scenarios [25].

The environmental balance has, in fact, "the goal of internalizing the environment in the choices of economy and of the use of space. [...] As much clearer than the financial statement, it stimulates the participation and communication of people, creating awareness of the relationship between the 
scarcity of environmental resources and the scarcity of financial resources and then of the values produced on the territory in respect of lost values (of use and of non-use)" [26].

The Environmental Accounting of a city can't be the same as that of a port area or of a port city, which, has to make into a system, two Environmental Accounting in order to obtain a model of integrated and sustainable governance.

\section{Proposals}

For future research it is necessary to propose specific guidelines for the development of an integrated system for environmental accounting, formulating a repeatable model, which can serve to identify scenarios of interventions consistent with the context of the port.

The European Commission, in the fifth and sixth Environmental Action Program, has strongly supported the Environmental Accounting systems for the governance of cities at all levels of planning: "The adoption of a system of environmental accounting at all levels of government allows policymakers to give an account to the communities governed about the environmental results and policies put in place, based on reliable data and information constantly updated on the state of environmental status, to integrate the "environment" variable in the decision-making of the public at all levels of government and, ultimately, to increase transparency about the effects of political powers' public environment [27]".

First of all, the port area Environmental Accounting system must be supported by a strategic city planning and by a port planning with some precise lines to follow, and for this, it has to be evaluated ex ante and ex post in respect of specific objectives and regulations.

The proposal of this research consists in a method of integration of the port planning with an Environmental Accounting system; in this way we can carry out different actions:

- Monitoring, measuring and evaluating the state of the natural environment subjected to the impacts of human actions;

- Assessing the monetary costs related to environmental protection and governance;

- Programming and reporting the use/consumption of natural resources.

This method aims to develop concrete actions by city and port administrations and to put together the development policies today separated from the operational point of view; the goal is the adoption of an integrated unit of quantification and comparison in the field of environmental sustainability, supporting the commitments of local Agenda 21 [28].

CLEAR (City and Local Environmental Accounting and Reporting) is an internationally approved method of environmental accounting like the integration of the AA1000 process, of the GRI reporting and of the report about the environmental spending SERIEE-EPEA. CLEAR includes a phase of accounting (collection and recording of data) and a phase of accountability (reporting), including in the system of governance stakeholders, and in the procedures the analysis and the evaluation of data and indicators.

The tool selects some Areas of Expertise for the management of environmental accounting in the cities and in the provinces, inside which we can identify the Fields of Accounting. 
Delivering the concepts of CLEAR in the port areas (excluding initially the rest of the urban fabric and then putting both into a system) the Areas of Expertise might be the following:

- Environmental management

- Natural environment and sea resources

- Emissions and waste

- Energy resources

- Land use

- Sustainable mobility

- Productive activities

- Training, information and participation

- Port-city integration [29]

The Areas of Expertise are the environmental matrices on which the various directive organs of a port can exercise the management functions. For each Area of Expertise it's possible to identify the following fields of reporting (see Table 2):

Table 2. Fields of Accounting specific for Port Areas [30].

\begin{tabular}{ll}
\hline Areas of expertise & Field of accounting \\
I.Environmental management & $\begin{array}{l}\text { Monitoring and management (the report is about the } \\
\text { condition of the air, soil and water and about the } \\
\text { environmental impacts of port activities) }\end{array}$ \\
Protection of biodiversity (the report is about the \\
and sea resources protection & $\begin{array}{l}\text { status of marine and terrestrial flora and } \\
\text { fauna and supervision and control activities) } \\
\text { Planning and implementation (the report is about } \\
\text { the development of indicators of waste } \\
\text { production and their recycling system) } \\
\text { Monitoring and control (the report is about the } \\
\text { impact of harmful emissions on the air, water and soil) } \\
\text { Planning and implementation (the report is about } \\
\text { the energy balance and about the promotion of } \\
\text { the use and the production of renewable energy) } \\
\text { Control (the report is about } \\
\text { the management of energy resources) }\end{array}$ \\
IV.Energy resources & $\begin{array}{l}\text { Protection and control (the report is about } \\
\text { the location of the different port activities) } \\
\text { Planning (the report is about the regulation } \\
\text { of the flow of public and private transport in } \\
\text { the port area and in the interface) } \\
\text { Industry, tourism and culture, trade, fishing and } \\
\text { handicraft (the report is about all activities that promote } \\
\text { sustainable development and the protection of cultural } \\
\text { heritage) }\end{array}$ \\
VI.Sand use &
\end{tabular}


Table 2. Cont.

\begin{tabular}{ll}
\hline Areas of expertise & Field of accounting \\
\hline & $\begin{array}{l}\text { Programming (the report is about the } \\
\text { training and the educational activities }\end{array}$ \\
VIII.Training, information & $\begin{array}{l}\text { for promoting environmental protection) } \\
\text { Cooperation (the report is about all subscriptions to the } \\
\text { project of National and International cooperation for } \\
\text { environmental protection and management) }\end{array}$ \\
& $\begin{array}{l}\text { Planning (the report is about the relationship with the port } \\
\text { plan and with the PRG measures of environmental protection) }\end{array}$ \\
\hline
\end{tabular}

The phase of the identification of the Areas of Expertise is followed by the description of Environmental Actions for the pursuit of some policies in a given time. Those actions are translated into Planned Activities. Taking into account the case of the Valencia port area, through the analytic phase of this research we can find these activities explained in the numerous projects that it joined; in reference to the reading of Table 1 (in reference to the colors associated with each project), we can elaborate a scheme of the action by the VPA management, in reference to the different project objectives. Thus, during the period 2006-2011 (taking into account the more profitable biennium 2007-2008), these were the Planned Activities of the Valencia environmental policy (see Table 3):

Table 3. Planned activities.

\begin{tabular}{|c|c|}
\hline Areas of expertise & Planned Activities \\
\hline \multirow[t]{8}{*}{ I.Environmental Management } & $\begin{array}{l}\text { Harmonization of the legislation and the procedures in } \\
\text { ports concerning the transportation of dangerous goods }\end{array}$ \\
\hline & $\begin{array}{l}\text { Compilation of a series of improvement criteria and action } \\
\text { plans designed to optimize energy efficiency globally and } \\
\text { particularly in PCTs }\end{array}$ \\
\hline & $\begin{array}{l}\text { Production of a good practice guide for noise } \\
\text { management in port areas and for action planning }\end{array}$ \\
\hline & Elaboration of the noise map of the Valencia port area \\
\hline & $\begin{array}{l}\text { Elaboration of the Inventory of the Greenhouse Gases } \\
\text { (GHG) Emissions }\end{array}$ \\
\hline & Calculation of the Carbon Footprint \\
\hline & Identification of Benchmarking and Best Practices \\
\hline & $\begin{array}{l}\text { Establishing an implementation standard for } \\
\text { Environmental Management Systems based on EMAS } \\
\text { certification }\end{array}$ \\
\hline $\begin{array}{l}\text { II.Natural environment and sea } \\
\text { resources protection }\end{array}$ & $\begin{array}{l}\text { Establishing criteria and indicators to monitor the effects of } \\
\text { port activities and their risk for the environment }\end{array}$ \\
\hline \multirow[t]{4}{*}{ III.Emissions and waste } & Reduction of noise pollution in the Valencia port area \\
\hline & Reduction of GHG emissions in theValencia port area \\
\hline & Expansion of air quality and noise pollution monitoring \\
\hline & Generation of less $\mathrm{CO}_{2}$ emissions \\
\hline \multirow[t]{2}{*}{ IV.Energy resources } & Energy efficiency improvement in PCT areas \\
\hline & $\begin{array}{l}\text { Improvement of the use of renewable energy through new } \\
\text { technological equipment installation }\end{array}$ \\
\hline V.Land use & $\begin{array}{l}\text { The smoother flow of traffic in and out of the terminal } \\
\text { allows cranes and handling equipment to be used more } \\
\text { efficiently and safely }\end{array}$ \\
\hline
\end{tabular}


Table 3. Cont.

\begin{tabular}{|c|c|}
\hline Areas of expertise & Planned Activities \\
\hline VI.Sustainable mobility & $\begin{array}{l}\text { Elaboration of a modal change in the transportation of } \\
\text { dangerous goods from land transport to maritime } \\
\text { transport } \\
\text { Management system application to PCT areas reducing } \\
\text { both their operating costs and their impact on the } \\
\text { environment }\end{array}$ \\
\hline VII.Productive activities & $\begin{array}{l}\text { Elaboration of a modal change in the transportation of } \\
\text { dangerous goods from land transport to maritime } \\
\text { transport } \\
\text { Management system application to PCT areas reducing } \\
\text { both their operating costs and their impact on the } \\
\text { environment through stock availability, repositioning } \\
\text { requirements, shelf-life constraints }\end{array}$ \\
\hline $\begin{array}{l}\text { VIII.Training, information and } \\
\text { participation }\end{array}$ & $\begin{array}{l}\text { Collection and dissemination of information and } \\
\text { improvement of the risk analysis processes for the } \\
\text { transportation of dangerous goods } \\
\text { Dissemination of the results of the project at a national } \\
\text { and international level in forums, associations, } \\
\text { congresses, etc... } \\
\text { Elaboration of a guideline approach for noise } \\
\text { management } \\
\text { Dissemination of the results of the project to other } \\
\text { European port communities and stakeholders through } \\
\text { maritime clusters } \\
\text { Development of a reference guide on environmental } \\
\text { improvement in fishing ports and marinas that is to be } \\
\text { distributed to other ports in Spain and at European level } \\
\text { Formulation of an environmental action plan in the } \\
\text { form of school visits to ports aimed at raising awareness } \\
\text { among the general public about the importance of } \\
\text { respecting the environment and preserving the marine } \\
\text { setting }\end{array}$ \\
\hline IX.Port-city integration & $\begin{array}{l}\text { Study of new coordination agreements between local } \\
\text { governments and ports to establish environmental action } \\
\text { plans in port settings } \\
\text { Establishment of a system of indicators that provides } \\
\text { real-time information on the environmental situation at } \\
\text { the port-city interface as well as results of corrective } \\
\text { measures applied to deal with any environmental problem } \\
\text { encountered }\end{array}$ \\
\hline & $\begin{array}{l}\text { Generation of positive impacts on the area surrounding } \\
\text { the terminal reducing noise pollution, easing congestion } \\
\text { and speeding up road traffic in the terminal vicinity }\end{array}$ \\
\hline
\end{tabular}

Taking into account the period of 2006-2011, we can try to elaborate a Final Environmental Accounting (final, because of the conclusion of the previous projects in 2011) evaluating the obtained results by a series of indicators.

The following Master Budget (Table 4) is based on the data elaboration of the VPA Annual Environmental Report [31] from 2006 to 2011; the indicators and units of measurement derive from the analysis of the resources referring to the nine Areas of Expertise individuated. 
Table 4. Master Budget.

\begin{tabular}{|c|c|c|c|c|c|c|}
\hline Areas of Expertise & Resource & Indicator & Definition & Unit & Reference value (2006) & Goal achieved (2011) \\
\hline $\begin{array}{r}\text { I.Environmental } \\
\text { management }\end{array}$ & - VPA management & $\begin{array}{l}\text { - Initiatives for mitigating } \\
\text { the environmental impacts }\end{array}$ & - Number of initiatives & - $\mathrm{n}^{\circ}$ & - 4 & - 2 \\
\hline \multirow[t]{4}{*}{$\begin{array}{l}\text { II.Natural environment } \\
\text { and sea resources } \\
\text { protection }\end{array}$} & - Air quality & - $\mathrm{CO}_{2}$ emissions & $\begin{array}{l}\text { Quantity of } \mathrm{CO}_{2} \text { Emissions: } \\
\text { - direct } \\
\text { - indirect }\end{array}$ & $\begin{array}{l}\text { - } \mathrm{t} \mathrm{CO}_{2}-\mathrm{e} \\
\text { - } \\
\mathrm{t} \mathrm{CO}_{2}-\mathrm{e}\end{array}$ & $\begin{array}{l}- \\
-\end{array}$ & $\begin{array}{ll}\text { - } & 214 \\
\text { - } & 1,136\end{array}$ \\
\hline & - Water quality & $\begin{array}{l}\text { - Water quality monitoring } \\
\text { results }\end{array}$ & $\begin{array}{l}\text { Ecological state of the } \\
\text { water }\end{array}$ & - Various & - & 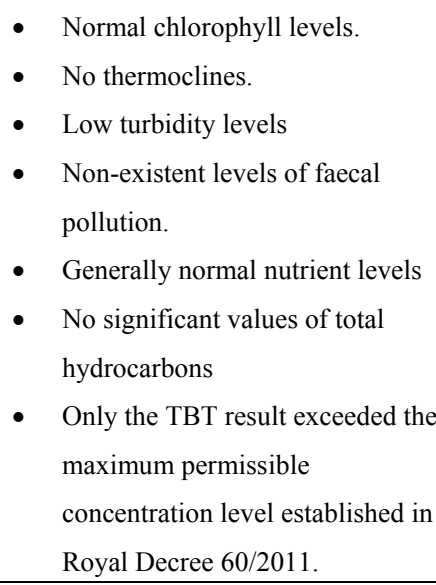 \\
\hline & - Biodiversity & - Biodiversity presence & $\begin{array}{l}\text { - } \mathrm{m}^{2} \text { of biodiversity } \\
\text { areas }\end{array}$ & - $\mathrm{m}^{2}$ & - & - $13,974.73$ \\
\hline & - $\quad$ Seabed & - Dredging management & - Dredged material & - $\mathrm{m}^{3}$ & - $8,284,992$ & - $1,437,598.63$ \\
\hline III.Emissions and waste & $\begin{array}{l}\text { - Soil, air and } \\
\text { water quality }\end{array}$ & $\begin{array}{ll}\text { - } & \text { Hazardous waste } \\
\text { - } & \text { Non-hazardous waste } \\
\text { - } & \text { Vessels generating waste } \\
\text { - } & \text { Valorized waste }\end{array}$ & $\begin{array}{l}\text { - } \quad \text { Tons of waste } \\
\text { - } \quad \text { Tons of waste } \\
\text { Waste removed } \\
\text { - } \quad \text { Marpol I } \\
\text { - } \quad \text { Marpol V } \\
\text { Percentage of valorized waste } \\
\text { - } \quad \text { Hazardous waste } \\
\text { - } \quad \text { Non-hazardous waste }\end{array}$ & $\begin{array}{ll}\text { - } & \mathrm{t} \\
\text { - } & \mathrm{t} \\
\text { - } & \mathrm{m}^{3} \\
\text { - } & \mathrm{m}^{3} \\
& \\
\text { - } & \% \\
\text { - } & \%\end{array}$ & $\begin{array}{ll}\text { - } & 1,7 \\
\text { - } & 24,8 \\
\text { - } & 20,666.06 \\
\text { - } & 11,807.44\end{array}$ & $\begin{array}{ll}\text { - } & 3,109 \\
\text { - } & 7.2 \\
\text { - } & 40,903.09 \\
\text { - } & 16,874.91 \\
& \\
\text { - } & 86.67 \% \\
\text { - } & 6.99 \%\end{array}$ \\
\hline
\end{tabular}


Table 4. Cont.

\begin{tabular}{|c|c|c|c|c|c|c|}
\hline Areas of Expertise & Resource & Indicator & Definition & Unit & Reference value (2006) & Goal achieved (2011) \\
\hline & - Noise quality & - Noise level & $\begin{array}{l}\text { - dBA level by Law } \\
\text { 7/2002 of the Valencia } \\
\text { Regional } \\
\text { Government }\end{array}$ & - $\mathrm{dBA}$ & - & $\begin{array}{l}\text { - Below the limit values of } 70 \text { and } \\
60 \mathrm{dBA}\end{array}$ \\
\hline IV.Energy resources & - Raw materials & - Electricity consumption & $\begin{array}{l}\text { - Mwh of electricity } \\
\text { consumed }\end{array}$ & - Mwh/year & - 3,300 & - $5,594.826$ \\
\hline V.Land use & - Soil & Public green areas & $\begin{array}{l}\text { Public green areas in the } \\
\text { port area: } \\
\text { - Grassy areas } \\
\text { - Gardens } \\
\end{array}$ & - $\mathrm{m}^{2}$ & $\begin{array}{ll}\text { - } & 34,38.93 \\
\text { - } & 11,099.83 \\
\end{array}$ & $\begin{array}{l}\text { - } 33,170.9 \\
\text { - } 13,327.7 \\
\end{array}$ \\
\hline VI.Sustainable mobility & - Raw materials & $\begin{array}{l}\text { - } \quad \text { Lead-free petrol } 98 \\
\text { consumption } \\
\text { - } \text { Gas oil A consumption } \\
\text { - Gas oil B } \\
\text { Consuption } \\
\end{array}$ & $\begin{array}{l}\text { - Litres of consumption } \\
\text { - Litres of consumption } \\
\text { - Litres of consumption }\end{array}$ & $\begin{array}{l}\text { - } 1 / \text { year } \\
\text { - } 1 / \text { year } \\
\text { - } 1 / \text { year }\end{array}$ & $\begin{array}{ll}\text { - } & 40,000 \\
\text { - } & 50,000 \\
\text { - } & 5,100\end{array}$ & $\begin{array}{ll}\text { - } & 35,986 \\
\text { - } & 9,844.367 \\
\text { - } & 3,840\end{array}$ \\
\hline VII.Productive activities & $\begin{array}{ll}\text { - } & \text { Soil } \\
\text { - } & \text { Water } \\
\text { - } & \text { Paper }\end{array}$ & $\begin{array}{ll}\text { - } & \text { Hazardous goods } \\
\text { - } & \text { Non-hazardous goods } \\
\text { - } & \text { Water consumption } \\
\text { - } & \text { Paper consumption }\end{array}$ & $\begin{array}{l}\text { - } \text { Tons of goods } \\
\text { - } \text { Tons of goods } \\
\text { - } \mathrm{m}^{3} \text { of water used for } \\
\text { port activities } \\
\text { - } \quad \text { Tons of Paper consumed } \\
\text { by port activities } \\
\end{array}$ & $\begin{array}{ll}\text { - } & \mathrm{t} \\
\text { - } & \mathrm{t} \\
\text { - } & \mathrm{m}^{3} \\
& \\
\text { - } & \mathrm{t}\end{array}$ & $\begin{array}{l}\text { - } \\
\text { - } \\
\text { - } 71,200 \\
\text { - } 16\end{array}$ & $\begin{array}{l}\text { - } 3,109 \\
\text { - } \quad 7.2 \\
\text { - } \quad 49,472 \\
\text { - } \quad 8,6\end{array}$ \\
\hline $\begin{array}{l}\text { VIII.Training, } \\
\text { information and } \\
\text { participation }\end{array}$ & $\begin{array}{l}\text { - } \\
\text { - } \\
\text { Diffuining courses } \\
\text { information }\end{array}$ & $\begin{array}{l}\text { - } \text { People involved } \\
\text { - } \quad \text { Publications } \\
\text { - } \quad \text { Congressses }\end{array}$ & $\begin{array}{ll}\text { - } & \text { Number of people } \\
\text { involved } \\
\text { - } & \text { Number of } \\
\text { publications } \\
\text { - } & \text { Number of } \\
\text { publications }\end{array}$ & $\begin{array}{ll}\text { - } & \mathrm{n}^{\circ} \\
\text { - } & \mathrm{n}^{\circ} \\
\text { - } & \mathrm{n}^{\circ}\end{array}$ & $\begin{array}{ll}\text { - } & 1,015 \\
\text { - } & 4 \\
\text { - } & 14\end{array}$ & $\begin{array}{ll}\cdot & 42 \\
- & 9 \\
- & 8\end{array}$ \\
\hline IX. Port-city integration & - Quality of life & - Protected areas & $\begin{array}{l}\text { Number of protected } \\
\text { areas }\end{array}$ & - $\mathrm{n}^{\circ}$ & - & - 2 \\
\hline
\end{tabular}


Environmental Costs (Tables 5 and 6) represent the economic and financial framework for the pursuit of the policies carried out in 2006 and in 2011.

Table 5. Environmental Costs, 2006.

\begin{tabular}{ll}
\hline Eco-management related costs & Cost $(€)$ \\
\hline Maintenance of meteorological stations & $6,603.75$ \\
Cleaning and management of oil spills in port waters & $5,484.17$ \\
General cleaning of port of Valencia waters & $102,341.16$ \\
Waste management-related costs in the ports & $231,264.54$ \\
Environmental consultancy costs & $73,204.51$ \\
Environmental communication & $193,492,31$ \\
Preventative measures & $2,072.20$ \\
Staff costs & $189,199.89$ \\
Accumulated depreciation & $148,308.75$ \\
Total cost & $\mathbf{9 5 1 , 9 7 1 . 2 8}$ \\
\hline
\end{tabular}

Table 6. Environmental Costs, 2011.

\begin{tabular}{ll}
\hline Eco-management related costs & Cost $(€)$ \\
\hline Repair and conservation & $212,239.84$ \\
Independent professional services & $393,850.12$ \\
Supplies and consumption & $5,695.94$ \\
Other services and costs & $336,681.93$ \\
Staff & $250,790.79$ \\
Depreciation of fixed costs & $282,322.41$ \\
Total cost & $\mathbf{1 , 4 8 1 , 5 8 1 . 0 3}$ \\
\hline
\end{tabular}

Observing the results of this research analysis with the CLEAR method, to obtain a healthy quality of life in port areas, through the VPA strategy for environmental sustainability, the future scenarios policy is oriented towards waste and emission management improvement. These processes comply with the regulatory requirements relating to environmental protection and this proposal can be an incentive to promote an innovative system of governance for port areas.

\section{Conclusions}

Environmental policy, translated into concrete action, gives valiant merits to a port authority that used a lot of resources (of various kinds) in the fight against climate change, in the reduction of harmful emissions, improving the quality of life of people who live along the port areas.

So the integration of a city with its waterfront is a transformation that involves both the waterfront and the inland urban core, activating processes based on urban revitalization and, at the same time, on the enhancement of the coastal area with a massive attention to environmental protection for human health.

In Italy the CLEAR approach is applied in urban areas (as is usual): in particular, we can take into account the city of Ferrara which, though close to the sea, is certainly not a port city. The local administration, promoting the environmental sustainability and the local Agenda 21, adopts CLEAR 
combined with an eco-budget for the Environmental Accounting of the city. In the Master Budget elaborated for 2005 [32] we can see that in the Areas of Expertise, the resources, the indicators are for a city not specifically for a port city: a more complex urban core with a very difficult environmental situation where there is the repeated and unsolved problem of the relation with the hinterland.

New integrated evaluation tools are required for managing the conflict between the port areas and the port cities. Integrated evaluation methods need a multicriteria-multidimensional analysis with new indicators to be concretely used to face this challenge, from the perspective of better implementation of the CLEAR approach.

The city of Valencia has been added to the list of those cities of the Mediterranean that have adopted strategies for recovery processes, for the exploitation of their waterfronts and for environmental protection, and they have achieved significant results in terms of socio-economic benefits, and have been projected onto the international scene through coherent strategic projects.

\section{Conflicts of Interest}

The author declares no conflict of interest.

\section{References and Notes}

1. Caroli, A. Il ruolo dei porti nel bacino del Mediterraneo (in Italian); pp. 53-65. Available online: http://www.openstarts.units.it/ (accessed on 5 September 2013).

2. Valenciaport (in Spanish). Available online: http:/www.valenciaport.com/ (accessed on 5 September 2013).

3. Oppido, S. Valencia: il Recupero Della Cultura Marittima per la Riqualificazione Urbana. In Città dal Mare. L'arte di Navigare e l'arte di Costruire le Città (in Italian); Clemente, M., Ed.; Editoriale Scientifica: Neaples, Italy, 2011; pp. 153-166.

4. Clemente, M. Città e Distretti Della Vela: Un Modello per lo Sviluppo Sostenibile del Territorio (in Italian); In Proceedings of the Metropoli IN-Transizione, Naples, Italy, 10 December 2005.

5. Dyndgaard, R. Environmental Management Systems. In A System Approach to the Environmental Analysis of Pollution Minimization; Jorgensen, S.E., Ed.; CRC Press: Boca Raton, FL, USA, 2000.

6. Abb. Available online: http://www.abb.com/ports (accessed on 5 September 2013).

7. Rovito, C. l'inquinamento atmosferico delle navi: annuali e approfondimento della connessa normativa internazionale e comunitaria (in Italian). Available online: www.dirittoambiente.net (accessed on 5 September 2013).

8. Clemente, M. Città dal Mare. L'arte di Navigare e l'arte di Costruire le Città (in Italian); Editoriale Scientifica: Neaples, Italy, 2012; p. 55.

9. Fusco Girard, L.; Baycan, T.; Nijkamp, P. Sustainable City and Creativity; Ashgate: Farnham, UK, 2012.

10. Nijkamp, P.; Kourtit, K.; de Kleijn, M. Facebook. 4 Urban. Facelift; Department of Spatial Economics: Amsterdam, The Netherlands, 2012.

11. García-Chicote, F.M. La Taula de Canvis. Aportacion a la historia de la contabilidad valenciana (siglos XIII-XVII) (in Spanish); Universitat de València: València, Spain, 2002. 
12. Rocchi, C. Storia di Bonacce e di Venti in Poppa. In AR Bimestrale dell'Ordine degli Architetti di Roma e Provincia (in Italian); Roma, Italy, 2005; pp. 17-20; Available online: http://www.edpr.it/ (accessed on 5 September 2013).

13. EMAS case studies. Available online: http://ec.europa.eu/environment/emas/casestudies/ port_valencia_en.pdf (accessed on 5 September 2013).

14. EC Europa. Available online: http://ec.europa.eu/environment/life/project (accessed on 5 September 2013).

15. Unige. Available online: http://www.fisica.unige.it/ (accessed on 5 September 2013).

16. Emas. Available online: http://www.ebah.com.br (accessed on 5 September 2013).

17. Port of Livorno. Available online: http://www.porto.livorno.it/ (accessed on 5 September 2013).

18. EC Europa. Available online: http://ec.europa.eu/environment/life/project/Projects/ index.cfm?fuseaction=search.dspPage\&n_proj_id=2714\&docType=pdf (accessed on 5 September 2013).

19. Climeport. Available online: http://www.climeport.com/en/project.html (accessed on 5 September 2013).

20. Bambara, W.; Gubiani, F.; Napoleoni, Q.; Rizzi, E. Gestione dei sedimenti tra innovazioni e rispetto dell'ambiente, l'applicazione della stabilizzazione di massa nella gestione dei fanghi di dragaggio per coniugare esigenze infrastrutturali e tempistiche di intervento contenendo l'impatto ambientale (in Italian). Available online: www.icop.it/tool/download.php (accessed on 5 September 2013).

21. Shippingtech. Available online: http://shippingtech.it/download\%20convegni\%202011/ green\%20ports/RafaelCompany.pdf (accessed on 5 September 2013).

22. Chrysogelos. Available online: http://chrysogelos.gr/files/ppts_1/Public\%20Hearing\%20\%20Port\%20of\%20Valencia.pdf (accessed on 5 September 2013).

23. Convenio (in Italian). Available online: http://www.valenciaport.com/esES/AreaProfesional/ ActualidadValenciaport/NoticiasValenciaport/Documents/R18\%20-\%20Convenio\%20Buenas\% 20practicas.pdf (accessed on 5 September 2013).

24. Cerreta, M.; de Toro, P. Valutazione d'impatto e Progetto Sostenibile. In Porti Turistici, Approccio Multidisciplinare per una Strategia Portuale Integrata (in Italian); Viola, P., Colombo, E., Eds.; Dario Flaccovio Editore: Palermo, Italy, 2000; p. 27.

25. Environmental Accounting. Available online: http://www.bilanciosociale.it/bilancioambientale.html (accessed on 5 September 2013).

26. Ferrara's Environmental Accounting. Available online: http://www.provincia.ferrara.it/sito?nav=204 (accessed on 5 September 2013).

27. Fusco Girard, L. La città, tra Conflitto, Contraddizione e Progetto (in Italian). ACE 2006, 1, 46-59.

28. The Recommendation of the Council of Europe on 2 March 2004.

29. Ferrari, M. Ferrara, il Processo di Agenda 21 Locale. In Città Attrattori di Speranza (in Italian); Fusco Girad L., You, N., Eds.; Franco Angeli: Milano, Italy, 2006.

30. Ferrara's Final Environmental Accounting. Available online: http://www.provincia.fe.it/ download/BAConsuntivo2010-2011_All.A_DCPnn.8059988del13.09.2012.pdf?server=sd2. provincia.fe.it\&db=/intranet/internet.nsf\&uid=0278786C7A505889C1257507002A59F8 (accessed on 5 September 2013).

31. Annual environmental report 06, APV. Available online: http://www.valenciaport.com/ Documents/MemoriaAmbiental_Ing_2006.pdf (accessed on 5 September 2013). 
32. Ferrara's Final Environmental Accounting. Available online: http://www.provincia.fe.it (accessed on 5 September 2013).

(C) 2013 by the author; licensee MDPI, Basel, Switzerland. This article is an open access article distributed under the terms and conditions of the Creative Commons Attribution license (http://creativecommons.org/licenses/by/3.0/). 